\title{
Gender Differences, Risk Attitude and Entrepreneurship in Kyrgyzstan
}

\author{
Asst. Prof. Dr. Raziya Abdiyeva (Kyrgyzstan-Turkey Manas University, Kyrgyzstan) \\ Dr. Burulcha Sulaimanova (Kyrgyzstan-Turkey Manas University, Kyrgyzstan) \\ Asst. Prof. Dr. Kamalbek Karymshakov (Kyrgyzstan-Turkey Manas University, Kyrgyzstan)
}

\begin{abstract}
This study analyses the role of risk attitude for entrepreneurship by gender differences in Kyrgyzstan. Multinomial probit analysis is applied to the data set drawn from the nationally representative survey "Life in Kyrgyzstan" for 2011. Entrepreneurship is measured through the agricultural and non-agricultural sample. Results of the study show that more risk-taking preferences are associated with higher entrepreneurship probability. However, this effect is not persistent for women in further estimations for non-agricultural entrepreneurship sample, while for men higher positive effect of risk loving behavior remains in off-farm self-employment too.
\end{abstract}

\section{Introduction}

Economic development requires development of entrepreneurship activity in economy. Along with such measures as strengthening legislature for private property rights or development of financial and other infrastructure, individual behavioral characteristics and perceptions are important for self-employment propensity of individuals.

Among these behavioral features empirical studies indicate that risk attitude of individuals is important factor for entrepreneurship choice of individuals (Hvide and Panos, 2013; Ekelund et al., 2005; Wagner, 2003). Moreover, majority of the papers revealed gender differentials in risk aversion behavior of individuals. In particularly, it is asserted that women are more risk averse than men (Bruce and Johnson, 1994; Eckel and Grossman, 2008; AlAjmi, 2011).

Following these empirical findings, it is of particular interest to study the risk tolerance effect on the of entrepreneurship of women. The aim of this paper is to analyze the effect of risk tolerance by gender on the choice of entrepreneurship in the specific case of Kyrgyzstan. To our best knowledge this study is the first that analyze the relation between risk attitude and entrepreneurship in Kyrgyzstan.

According to the World Bank (2012) 59 percent of women and 75 percent of the male population between 15 and 64 years of age in 2008 were in the labor force. Female labor force participation rates in emerging Europe and Central Asia are near the global average, but the male participation rates are well below the global average. According to the National Statistical Committee (2015) of Kyrgyz Republic in 2014, $45.6 \%$ of women were employed. Most of them are employed in services sectors, such as education, healthcare, real estate etc. In Europe and Central Asia region Kyrgyzstan are among the countries with higher rates of female participation in ownership (World Bank, 2012:66).

This study draws on the nationally representative cross-sectional data, where responses of respondents are used as subjective measure of the risk tolerance of individuals. Binary response logit models are applied for empirical estimation.

The paper is structured as follows: In the Section 2 literature review on risk tolerance and entrepreneurship, taking into account gender differentials, is given. Section 3 describes data and provides with summary statistics. Section 4 includes empirical methodology and Section 5 discusses results of estimation. Section 6 concludes.

\section{Literature Review}

Risk attitude of individual can affect his/her choices and decisions. Bonin et al. (2007) find that the more risk lover individuals select occupations with higher wages and higher variation in wages. Dohmen and Falk (2005) with complementary laboratory experimental study showed that relatively risk averse workers prefer fixed payments than variable payment schemes such as piece-rate or tournament contracts.

More risk lovers are more likely to choose entrepreneurship than wage employment. According to some theoretical and empirical studies (Wagner, 2003; Ekelund et al., 2005) entrepreneurship requires making risky decisions in an uncertain environment. So only those persons who are able to bear higher risks may start as an entrepreneur. From this point of view, the risk attitude of a person is one of the crucial variables in a person's choice between entrepreneurship and a salaried job (Caliendo et al, 2006).

Guiso and Paiella (2004) find that less risk averse individuals are more likely to be self-employed. Also several other empirical studies revealed that more risk lover men more inclined to be engaged in entrepreneurship as selfemployed (Hartog et al., 2002; Guiso and Paiella, 2004; Ekelund et al., 2005; Dohmenet al.,2005; Kan and Tsai, 2006; In Soo Cho, 2011). On the other hand, some studies found mixed results related the effect of risk attitude of 
individuals on the choice of entrepreneurship. Rosen and Willen (2002) came to conclusion that risk attitude is not a dominant factor in his/her decision to start an own business. Cramer et al. (2002) too could not be confident enough to conclude that there is causality link between risk aversion and entrepreneurial selection of individual. Also, Blanchflower and Oswald (1998) found positive correlation between the wealth status of a person and his/her risk attitude.

Generally empirical studies showed that women are more risk averse than men (e.g., Bruce and Johnson, 1994; Hartog et al., 2002; Eckel and Grossman, 2008; Croson and Gneezy, 2009; Al-Ajmi, 2011; Çağlayan and Abdieva, 2014). Charness and Gneezy (2012) found a strong difference in investment behavior across gender and results showed that women make smaller investments in the risky asset than do men, and so appear to be financially more risk averse. Soo Cho (2011) using 1979 National Longitudinal Surveys of Youth data and multinominal logit model find that more risk tolerant men are more likely to enter self-employment but they didn't find any significant effect of risk tolerance on women's entrepreneurship.

Brody (1993) affirms that in anticipation of negative outcomes, women report more nervousness and fear than men, thus it is logical that women are more risk averse when facing a risky situation. Niederle and Vesterlund (2007) and Soll and Klayman (2004) have found that men are more overconfident than women.

According to several studies gender differences in risk attitude is eliminated with experience and profession. Atkinson, Baird and Frye (2003) analyzed mutual fund managers and didn't found gender differences in the way funds are managed in terms of performance and risk. Johnson and Powell (1994) found differences among the non-managerial population, but did not observe such differences in the managerial population (managers and potential managers with management education).

There are several studies focusing risk attitude and gender relationship in Kyrgyzstan case. Çağlayan and Abdieva (2014) investigated risk tolerance of individual investors in Kyrgyzstan case. Using multinomial logit model they found that men are more risk lovers than women in Kyrgyzstan. When the age increases people become less risk lover. Having non-wage income increases taking risk and increases in the rate of investment. The findings also indicate that income has a positive effect on the risk tolerance. Abdieva et al. (2015) analyzed the determinants of the risk tolerance in Kyrgyzstan. The results of multinomial probit models showed that men more willing to take risk and that as the age increases individuals become risk-averse. Increasing income and education level has a positive effect on the risk taking decision of the individual. The regional distribution of risk tolerance of individuals shows that individuals living in rural areas and in south region are more likely to be in risk-averse category. Results of study by Esenaliev and Anderson (2015) on gender wage gap in Kyrgyzstan showed that the level of gender wage gap is $24-30 \%$, and risk attitude is used as one of the possible factors for explaining this.

Although these studies explore empirical evidence on risk attitude by gender and raise its importance as potential factor for wage earnings differentials, to our best knowledge studies did not focus on the risk attitude and entrepreneurship activities by gender in case of Kyrgyzstan. This paper aims to fill this gap.

\section{Methodology}

The decision of individual to be entrepreneur has binary response character, which calls for using binary response Logit models, which are conditional on individual and household characteristics. Formally, model is given below (Wooldridge, 2005):

$$
\begin{gathered}
P\left(y_{i}=1 \mid x_{i}\right)=G\left(\beta_{0}+\beta_{1} x_{1}+\cdots+\beta_{k} x_{k}\right)=G\left(\beta_{0}+x \beta\right) \\
G(z)=\frac{\exp (z)}{[1+\exp (z)]}=\Lambda(z)
\end{gathered}
$$

where $\mathrm{G}$ is the logistic function. $y_{i}$ is the discrete dependent variable, taking values of zero or one, showing the probability of individual to be entrepreneur; $x_{i}$ is the vector of variables at individual level, which includes individual's age, marital status and education level and household levels variables, which includes household composition, expenditure level, regional characteristics (for detailed description of variables see Table A.1. in appendix).

Occupational choices of individuals are based on their employment status given in the questionnaire. It should be noted that in this paper entrepreneurship is measured in a broad sense and those who indicate their wage employment as the own-account worker are grouped as the entrepreneurs. However, this broad definition of entrepreneurship may give biased results, since in most of the developing countries not all own-account working activities can be considered as entrepreneurship. As Karymshakov et al. (2016) note in Kyrgyzstan members of household who own land are considered as own-account workers. In this case it appears that even if individuals just work as family worker in agriculture with low productivity, they may be considered as own-account workers. Therefore, working in agriculture as own-account worker may not have characteristics of entrepreneurs. This fact raises the necessity for measurement of entrepreneurship in in-farm and off-farm sector. Following this issue we estimate the model by agriculture and non-agriculture sector. 
In the dataset Life in Kyrgyzstan for 2011 used for this study, there is a special section on subjective well-being of individual, where individual is asked particular question on how they asses their risk tolerance, as person who is fully willing to take risks or a person avoiding taking risks, which is measured from 0 to 10 . The answer for this question is taken as the main explanatory variable. From these answers three categories of risk tolerance are formed: risk-averse individuals (from 0 to 3), risk-neutral (from 4 to 6) and risk-lovers (from 7 to 10).

\section{Data and Descriptive Statistics}

In this study the risk attitude and gender behavior impact on entrepreneurial decision is investigated based on the second wave of "Life in Kyrgyz Republic" survey data, which was conducted by DIW Berlin in collaboration of Humboldt University of Berlin, the Center for Social and Economic Research (CASE-Kyrgyz Republic), and the American University of Central Asia (AUCA) in 2011. This survey includes wide range information both on individual and household level and representative at the national level.

The table 1 describes the main individual and household characteristics both for men and women. The total amount of observation is equal to 7340 individuals between $15-65$ ages, where $52.67 \%$ are women. The mean age of sample is 37.51 years, and there is no significant difference in ages between genders. While marital status of women is higher than men, showing that women have more propensities to be married rather than men. The education attainment shows that both men and women more likely to have basic or secondary education, while men more likely to have technical education and women more inclined to have tertiary education.

\begin{tabular}{|c|c|c|c|c|c|c|}
\hline & \multicolumn{2}{|c|}{ Total sample } & \multicolumn{2}{|c|}{ Men } & \multicolumn{2}{|c|}{ Women } \\
\hline & Obs. & $\%$ & Obs. & $\%$ & Obs. & $\%$ \\
\hline \multicolumn{7}{|l|}{ Individual characteristics: } \\
\hline Age (mean) & 7340 & 37.51 & 3474 & 37.35 & 3866 & 37.64 \\
\hline Marital status $(1=$ married $)$ & 5914 & 80.57 & 2666 & 76.74 & 3248 & 84.01 \\
\hline \multicolumn{7}{|l|}{ Education level: } \\
\hline - $\quad$ Basic or secondary & 4752 & 64.74 & 2258 & 65.00 & 2494 & 64.51 \\
\hline - $\quad$ Technical & 1299 & 17.70 & 664 & 19.11 & 635 & 16.43 \\
\hline - $\quad$ Tertiary & 1253 & 17.07 & 533 & 15.34 & 720 & 18.62 \\
\hline \multicolumn{7}{|l|}{ Risk attitude: } \\
\hline - $\quad$ Risk lover & 2066 & 28.15 & 1255 & 36.13 & 811 & 20.98 \\
\hline - $\quad$ Risk neutral & 3010 & 41.01 & 1401 & 40.33 & 1609 & 41.62 \\
\hline - $\quad$ Risk averse & 2262 & 30.82 & 818 & 23.55 & 1444 & 37.35 \\
\hline \multicolumn{7}{|l|}{ Household characteristics: } \\
\hline Household size (mean) & - & 5.3609 & - & 5.3972 & - & 5.3282 \\
\hline Children ratio (0-5 years) (mean) & - & 0.1120 & - & 0.1113 & - & 0.1125 \\
\hline Expenditure per capita (mean) & - & 38363.1 & - & 37768.4 & - & 38897.5 \\
\hline Residence $(1=$ rural $)$ & 45594 & 62.59 & 2229 & 64.16 & 2365 & 61.17 \\
\hline \multicolumn{7}{|l|}{ Regions: } \\
\hline - North & 1143 & 15.57 & 555 & 15.98 & 588 & 15.21 \\
\hline - $\quad$ South & 3647 & 49.69 & 1717 & 49.42 & 1930 & 49.92 \\
\hline - Central & 2550 & 34.74 & 1202 & 34.60 & 1348 & 34.87 \\
\hline
\end{tabular}

Table 1. Descriptive Statistics Source: LIK 2011 data

The risk attitude indicators show that $36.13 \%$ and $20.98 \%$ of men and women count their self as risk lovers respectively, while $23.55 \%$ and $37.35 \%$ of men and women report their self as risk-averse person. Precisely, men more likely to take risk rather than women do.

The household characteristics do not display gender differences, and in general the average household size consist of 5 people, the ratio of children in the household with respect to household size is around 0.11 and total expenditure per capita in household is around 38 thousand soms. More than half of individuals reside in rural areas and most of observation comes from south regions, which are highly populated.

\section{Estimation Results}

The estimation results for entrepreneurial decision of the individual are given in the Table 2. Almost all estimated parameters have expected signs. The primary variable of interest, the impact of risk attitude of individual on decision to be entrepreneur shows that risk lovers more likely to be self-employed, and that there is significant gender difference on impact of risk attitude on labor supply decision. Thus, risk-lover women more likely to be entrepreneur, but this effect is not significant in further estimations by agricultural and non-agricultural samples. Women with risk averse preferences have less probability to be entrepreneur in non-agricultural sector. Interestingly, risk effect for men is more evident in non-agricultural sector. Risk lover men show higher probability 
to be entrepreneur in non-agricultural sector, while in agricultural sector it shows negative effect. Moreover, the risk averse preferences have less negative effect for off-farm entrepreneurship for men.

There is statistically significant impact of age on the individuals' decision to engage in entrepreneurial activities, thus with increase of age individual more likely to be entrepreneur, however after definite ages this probability decreases. Generally marital status of individual is positively correlated with decision to be entrepreneur, while there is no significance of marital status on entrepreneurs working in agricultural sector, especially if they are women. The educational level of individual shows that, with higher education individuals more likely to be working in other occupation types. While having technical or tertiary education do not present any impact on decision of individual to be self-employed in agricultural sector.

The household composition has twofold impact on entrepreneurship. While the size of household does not influence the entrepreneurship, the ratio of children (0-5 years) with respect to the total size of household size impacts the decision of individuals of men and women differently. Hence with increase of children ratio the probability of men to be self-employed is increasing, while for women is decreasing.

The per capita expenditure level of household has significant influence on individual decision to be entrepreneur in non-agricultural sector and general positive correlation with women decision to engage in self-employment both in agricultural and non-agricultural sectors. The residence of household in rural area is increasing the probability of individual to be self-employed in agricultural sector rather than in non-agricultural sector. Moreover, the regional characteristics of household show that individuals from north area more likely to be working in own account in agricultural sector, while in south region individuals more likely to conduct theirselves to selfemployment in non-agricultural sector.

\begin{tabular}{|c|c|c|c|c|c|c|c|c|c|}
\hline & \multicolumn{3}{|c|}{ Total sample } & \multicolumn{3}{|c|}{ Agricultural sector } & \multicolumn{3}{|c|}{ Non-agricultural sector } \\
\hline & Total & Men & Women & Total & Men & Women & Total & Men & Women \\
\hline \multicolumn{10}{|c|}{ Individual characteristics } \\
\hline Age & $0.04 * * *$ & $0.061^{* * *}$ & $0.021 * * *$ & $0.054 * * *$ & $0.067 * * *$ & $0.021 *$ & $0.028 * * *$ & $0.038 * * *$ & $0.016 * * *$ \\
\hline Age squared & $-0.0005 * * *$ & $-0.0007 * * *$ & $-0.0002 * * *$ & $-0.0005^{* * *}$ & $-0.0006^{* *}$ & -0.0002 & $-0.0003 * * *$ & $-0.0004 * * *$ & $-0.0001 * * *$ \\
\hline $\begin{array}{l}\text { Marital status } \\
(1=\text { married })\end{array}$ & $0.045^{* * *}$ & $0.132 * * *$ & $0.030 * *$ & 0.068 & $0.146^{* *}$ & 0.088 & $0.036 * * *$ & $0.095 * * *$ & $0.019^{*}$ \\
\hline Education level: & & & & & & & & & \\
\hline - Technical & -0.015 & $-0.063 * * *$ & 0.003 & 0.068 & 0.015 & 0.015 & -0.001 & $-0.0312 *$ & 0.11 \\
\hline - Tertiary & $-0.078 * * *$ & $-0.136^{* * *}$ & $-0.026 * * *$ & 0.068 & -0.007 & 0.051 & $-0.044 * * *$ & $-0.080 * * *$ & $-0.014 *$ \\
\hline \multicolumn{10}{|c|}{ Household characteristics } \\
\hline $\begin{array}{l}\text { Household size } \\
\text { Children ratio }\end{array}$ & 0.002 & -0.002 & 0.003 & -0.001 & $-0.018 *$ & 0.005 & $0.006 * * *$ & $0.008^{*}$ & $0.004 * *$ \\
\hline (0-5 years) & 0.032 & $0.126^{* *}$ & $-0.068 * *$ & $0.337 * * *$ & $0.324 * *$ & -0.067 & 0.014 & $0.0960^{*}$ & $-0.050^{*}$ \\
\hline $\begin{array}{l}\text { Expenditure per } \\
\text { capita }\end{array}$ & 0.015 & 0.012 & $0.019 * *$ & 0.042 & 0.28 & $0.088 * *$ & $0.035 * * *$ & $0.058 * * *$ & $0.016^{* *}$ \\
\hline $\begin{array}{l}\text { Residence } \\
(1=\text { rural })\end{array}$ & $0.049 * * *$ & $0.109 * * *$ & -0.003 & $0.168 * * *$ & $0.178^{*}$ & 0.059 & $-0.034 * * *$ & $-0.041 * *$ & $-0.020 * * *$ \\
\hline Regions: & & & & & & & & & \\
\hline - North & $0.010^{* * *}$ & $0.243^{* * *}$ & 0.012 & $0.193 * * *$ & $0.255 * * *$ & 0.083 & -0.009 & 0.031 & -0.009 \\
\hline - South & $0.058^{* * *}$ & $0.102 * * *$ & $0.025^{* *}$ & -0.008 & $0.140 * * *$ & -0.017 & $0.048 * * *$ & $0.088^{* * *}$ & $0.015^{*}$ \\
\hline Risk attitude: & & & & & & & & & \\
\hline - Risk lover & $0.055^{* * *}$ & 0.015 & $0.025^{* *}$ & -0.010 & $-0.121 * * *$ & 0.050 & $0.043 * * *$ & $0.046 * *$ & 0.010 \\
\hline - Risk averse & $-0.065 * * *$ & $-0.073 * * *$ & $-0.024 * * *$ & $-0.083 * *$ & $-0.109 * *$ & -0.025 & $-0.042 * * *$ & $-0.0411 * *$ & $-0.021 * * *$ \\
\hline No. of Obs. & 7340 & 3474 & 3866 & 1603 & 1025 & 578 & 5737 & 2449 & 3288 \\
\hline LR chi2 & $740.4^{* * *}$ & $621.7 * * *$ & $188.9^{* * *}$ & $291.7 * * *$ & $324.9 * * *$ & $37.1 * * *$ & $376.90 * * *$ & $213.10^{* * *}$ & $155.68 * * *$ \\
\hline Log likelihood & -3372.33 & -1917.95 & -1044.91 & -965.18 & -496.23 & -279.31 & -1984.48 & -1146.42 & -711.03 \\
\hline Pseudo R2 & 0.0989 & 0.1395 & 0.0829 & 0.1313 & 0.2467 & 0.0624 & 0.0867 & 0.0850 & 0.0987 \\
\hline
\end{tabular}

Table 2. Logit Estimation Results for Entrepreneurship (Marginal Effect Estimates)

\section{Conclusion}

Development of entrepreneurship activities for developing countries is important long-term objectives, which may depend on many factors ranging from government policies to other formal measures. Along with these factors, individual risk-tolerance characteristics are important for carrying out entrepreneurial activities.

The objective of this paper was to study the impact of risk tolerance over the entrepreneurship by focusing on the gender and non-agricultural sector of employment. This study applied binary response techniques on the large nationally representative cross-sectional data. In general, estimation results showed that individual preferences for taking more risk have positive effect over the entrepreneurship. However, further estimations by gender and non- 
agricultural sector revealed that women entrepreneurship in off-farm sectors is not associated with risk loving behavior. However, the effect of risk loving over the entrepreneurship remains in non-agricultural sector for men.

Thus, although risk tolerance important for entrepreneurship, this effect may not be strong through all sector of employment and among men and women. Especially these results suggest that agricultural and non-agricultural measurement of entrepreneurial activities should be taken into account in order to have the true picture of entrepreneurship. For more comprehensive exploration of the relationship between risk tolerance and entrepreneurship further studies may test the reverse causality - changes in risk preferences after being entrepreneur.

Findings of this paper to some extent underline the fact that women entrepreneurship in off-farm sector of employment in Kyrgyzstan case is limited. Therefore, development of entrepreneurial activities among women in off-farm sector requires in priority government policies oriented supporting women self-employment.

\section{References}

- Abdieva, R., Karymshakov, K. and B. Sulaimanova, 2015. "Determinants of Risk Tolerance: Empirical Evidence from Kyrgyzstan", Annual "Life in Kyrgyzstan" Conference, 1-2 October 2015, Bishkek

- Al-Ajmi, J. Y. 2011. "Risk Tolerance of Individual Investors in an Emerging Market". Journal of Risk and Diversification. ISSN 1986-4337 Issue 2.http://www.journalofriskanddiversification.com

- Atkinson, S. M., Baird, S. B. and Frye, M. B. 2003. "Do female mutual fund managers manage differently?" Journal of Financial Research, 26(1), 1-18.

- Blanchflower, D., and A. Oswald , 1998. "What makes an Entrepreneur?” Journal of Labor Economics, 16, 26-60.

- Bonin, H., Dohmen, T., Falk, A., Huffman, D., and Sunde, U. (2007) Cross-sectional earnings risk and occupational sorting: The role of risk attitudes, Labour Economics, 14, 926-937

- Brody, L. R. (1993). On understanding gender differences in the expression of emotions. In Human Feeling: Explorations in Affect Development and Meaning, ed. S. L. Ablon, D. Brown, E. J. Khantzian and J. E. Mack, (pp. 87-121). Hillsdale, N.J.: Analytic Press.

- Bruce, A. and Johnson, J., 1994, "Male and female betting behavior: new perspectives," Journal of Gambling Studies 10, 183-98.

- Çağlayan, E. and R. Abdieva 2014. "How ‘s the Risk Tolerance of Individual Investors in Kyrgyzstan?", Asian Economic and Financial Review, Volume 4, Number 3, p.404-415.

- Caliendo, M., Fossen F. and Kritikos, A. 2006. Risk Attitudes of Nascent Entrepreneurs: New Evidence from an Experimentally-Validated Survey, IZA DP No. 2168, DISCUSSION PAPER SERIES, Forschungsinstitutzur Zukunft der Arbeit, Institute for the Study of Labor, June.

- Charness, G. and U., Gneezy, 2012. "Strong Evidence for Gender Differences in Risk Taking”, Journal of Economic Behavior \& Organization, 83:50-58

- Cramer, J., J. Hartog, N. Jonker, and C. Van Praag 2002. "Low Risk Aversion encourages the choice for entrepreneurchip: an empirical test of a truism", Journal of Economic Behavior and Organization, 48, 2936.

- Croson, R., Gneezy, U. 2009. "Gender Diferences in Preferences", Journal of Economic Literature, 47, 448474

- Dohmen, T., A. Falk, D. Huffman, U. Sunde, J. Schupp, and W. Wagner (2005): "Individual Risk Attitudes: New Evidence from a Large, Representative, Experimentally-Validated Survey," IZA Discussion Paper, 1730.

- Dohmen, T., and A. Falk 2005. "Performance Pay and Sorting - Productivity, Preferences and Gender," IZA Working Paper.

- Eckel, C.C., Grossman, P.J. 2008. "Forecasting Risk Attitudes: An Experimental Study Using Actual and Forecast Gamble Choices", Journal of Economic Behavior and Organization, 68: 1-17

- Ekelund, J., E. Johansson, M.-R.J"arvelin, and D. Lichtermann, 2005. "Self-Employment and Risk Aversion - Evidence from Psychological Test Data," Labour Economics, 12(5), 649-659.

- Gary Charness and Uri Gneezy, 2012. "Strong Evidence for Gender Differences in Risk Taking", Journal of Economic Behavior \& Organization, 83:50-58.

- Guiso, L., Paiella, M. 2004. The Role of Risk Aversion in Predicting Individual Behavior, CEPR Discussion Paper, 4591

- Hans K. Hvide and Georgios A. Panos, 2013. Risk Tolerance and Entrepreneurship, IZA Discussion Paper No. 7206 February 
- Hartog, J., Ferrer-i-Carbonell, A., Jonker, N. 2002. "Linking Measured Risk Aversionto Individual Characteristics", Kyklos, 55, 3-26

- In Soo Cho, 2011.Do Gender Differences in Risk Preferences Explain Gender Differences in Labor Supply, Earnings or Occupational Choice? Working Paper No. 11022, December, IOWA STATE UNIVERSITY, Department of Economics.

- Johnson, J. E. and Powell, P. L., 1994. “Decision making, risk and gender: are managers different?”, British Journal of Management, 5(2), 123-138.

- Kan, K. and Tsai, W., 2006. "Entrepreneurship and risk aversion”, Small business economics, 26, 465-474.

- Karymshakov, K., Abdieva, R., Sulaimanova, B., \& Sultakeev, K., 2016. Remittances impact on youth labour supply: evidence from Kyrgyzstan (2016-05 No. PEP)

- National Statistical Committee of Kyrgyz Republic, 2015. Women and Men in Kyrgyz Republic, 20102014 years (in Russian). http://stat.kg/media/publicationarchive/534f0c98-fb76-4922-b8c16b8b8f44ba27.pdf

- Niederle, M. and Vesterlund, L., 2007. "Do women shy away from competition? Do men compete too much?”, Quarterly Journal of Economics, 122(3), 1067-1101.

- $\quad$ Rosen, H., and P. Willen, 2002. "Risk, Return and Self-employment," Discussion Paper, University of Princeton.

- Soll, J. B. and Klayman, J., 2004. “Overconfidence in interval estimates”, Journal of Experimental Psychology: Learning, Memory and Cognition, 30(2), 299-314.

- Wagner, J. 2003. "The Impact of Personal Characteristics and the Regional Milieu on the Transition from Unemployment to Self-Employment: Empirical Evidence for Germany," Jahrb ücherf "urNational"okonomie und Statistik, 223(2), 204-221.

- Wooldridge, J. M., 2005. Introductory econometrics: a modern approach.

- World Bank, 2012. Sarosh Sattar. Opportunities for Men and Women: Emerging Europe and Central Asia Women in Entrepreneurship, Chapter three Women Entrepreneurship http://siteresources.worldbank.org/ECAEXT/Resources/258598-1322580725430/chReferences 